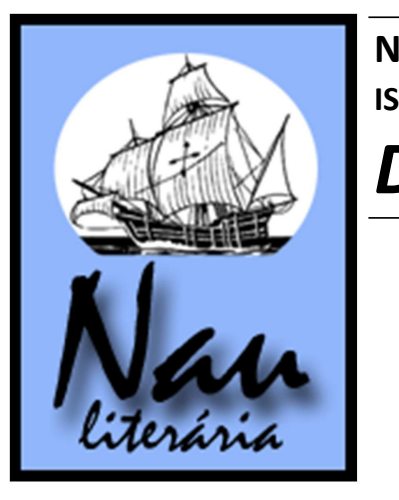

\title{
Rosita, de Moçambique
}

Resumo: O presente artigo propõe a análise de um encontro entre ficção e realidade, na poética de Mia Couto, através do conto "Rosita", publicado em $\mathrm{Na}$ berma de nenhuma estrada. Procuramos identificar essa possibilidade através do diálogo entre a simbologia da água, a constituição da imagem e o registro da memória.

Palavras-chave: Mia Couto; simbologia; imagem; memória.

\section{Neiva Kampff Garcia}

\begin{abstract}
The present article aims at analyzing a meeting of fiction and reality in the poetics of Mia Couto through the short story "Rosita", published in Na berma de nenhuma estrada. We attempt to identify that possibility through the dialogue between the symbology of water, the constitution of the image and the register of memory.
\end{abstract}

Keywords: Mia Couto; symbology; image; memory.

O segredo do escritor é anterior à escrita. Está na vida, está na forma como ele está disponível a deixar-se tomar pelos pequenos detalhes do cotidiano ${ }^{l}$.

A ficção, enquanto capacidade inventiva do ser humano, revitaliza o olhar dele sobre os seus tempos (passado, presente, futuro) e de sua nação, permitindo-lhe uma maior compreensão sobre si mesmo e sobre o seu espaço. Arquiteto de sua própria história, o homem conta o que viveu e vive, o que lhe narraram e o que acredita. Assim, vai elaborando a ficção de um contador de histórias e, quando esta se formaliza na escrita, possibilita a transmissão - íntegra e atemporal - desse conhecimento para outras sociedades, quaisquer que sejam as suas geografias.

Mia Couto é um desses contadores de histórias. Biólogo, professor e consagrado escritor moçambicano, destaca-se pela publicação de romances, contos e crônicas, tendo já adentrado na poesia e na prosa infanto-juvenil, bem como no texto teatral. Comumente sua produção é apontada como possuidora de uma preocupação voltada à discussão da moçambicanidade, projeto no qual propõe uma construção identitária que atravessa idéias

\footnotetext{
* Licenciada em Letras pela UFRGS, com habilitação em Língua Portuguesa e Literaturas de Língua Portuguesa (2006) e Especialista em Literatura Brasileira pela mesma universidade (2008). Tem Mestrado em Estudos de Literatura, especialidade Literaturas Portuguesa e Luso-Africanas pela UFRGS.

${ }^{1}$ A epígrafe é parte do texto elaborado para crianças lusófonas integradas no programa interescolar "Ciência Viva", julho de 2004 e está publicada em COUTO, 2005, p. 46 sob o título: Uma palavra de conselho e um conselho sem palavras.
} 
como "criar um novo olhar, inventar outras falas e ensaiar outras escritas" (COUTO, 2005, p.22).

Em muitas oportunidades, o escritor tem reiterado que suas estórias traduzem as vozes que ouve no cotidiano e se nutrem das observações do universo cultural multifacetado a que tem acesso nas suas andanças como biólogo. Seus textos refletem sistemas de pensamento, linguagens, acontecimentos míticos e históricos que compõem a dinâmica de identidades ao seu redor. Em suas palavras: “o território da narração não é um lugar mas é a própria viagem. O discurso está em constante mutação e os diferentes personagens têm diferentes vozes que dialogam" (COUTO, 2005, p.112).

A referida "viagem" é constituída pela imaginação, pertença interior de quem cria, e pela sensibilidade de quem capta no mundo as pertenças alheias. Mia Couto é um cidadão que faz da literatura uma ponte entre duas margens: o território da narração e o da nação. Nessa perspectiva, acompanhamos as considerações de Fonseca e Cury:

\begin{abstract}
Da viagem real ao deslocamento imaginário, do cruzamento de tempos à crítica do presente, os textos de Mia Couto inserem-se tanto na releitura da história como na ficcionalização da condição do homem contemporâneo. Muitas vezes, o escritor parte de fatos históricos, de acontecimentos "reais", para neles inserir vozes que a história reprimiu, para reler acontecimentos reinventando seu contexto, envolvendo-os com uma aura de fantasia, hipertrofiando o real ao atravessá-lo pelas visões míticas que marcam seu projeto literário. (FONSECA e CURY, 2008:83-84, grifo das autoras)
\end{abstract}

A "releitura da história" e a "ficcionalização da condição do homem contemporâneo", referidas pelas autoras, é o que percebemos como uma noção mais ampla de literatura, presente em Mia Couto, que possibilita uma dinâmica constante de atualização do real e da ficção. A natureza do seu texto é a de hibridez cultural instaurada pelos múltiplos diálogos que promove, entre seres fictícios e/ou reais, simbologias e/ou fatos do cotidiano presencial. As relações polifônicas que estabelece são dinâmicas e convidam o leitor a instaurar sua própria capacidade de sonhar, objetivo fundamental de um escritor que, nas palavras de Mia, "não é apenas aquele que escreve. É aquele que produz pensamento, aquele que é capaz de engravidar os outros de sentimento e de encantamento" (COUTO, 2005, p. 63).

O conto "Rosita", objeto de nossa análise, encerra a publicação Na berma de nenhuma estrada, cuja primeira edição data de abril de 2001, reunindo vinte e oito pequenas estórias publicadas em jornais e revistas nas décadas de 1990 e 2000. As temáticas abordadas são diversas, inclusive as que retomam tempos coloniais, preenchendo uma das possibilidades de apreensão do título: uma estrada sem margens inexiste como tal, tornando-se um espaço amplo, sem limites; uma margem que não delimita remete, igualmente, a um sentido de amplidão, transformando-se apenas num ponto referencial. Carmem Lucia Secco alude que: 
Com o estilo que sempre o singularizou, Mia Couto nessa obra continuou a recriar palavras e a reinventar ludicamente a linguagem, trazendo cenas e experiências da sua infância. Há em quase todas as narrativas a procura da dimensão humana que os anos de guerra e barbárie sufocaram em Moçambique [...]. (SECCO, 2006, p.291)

Percorrendo cada um dos textos, vamos descobrindo que um viés da leitura é sobre a força de superação, a capacidade de retomar a esperança e seguir em frente, não importando o tempo necessário para essa ação. Tal abordagem comunga com a colocação de Maria Fernanda Afonso:

De início, seríamos tentados a atribuir-lhe um tom pessimista, pensando num caminho sem saída, mas finalmente concluímos que se trata de um projecto a construir por todo um povo que busca a individualidade, libertando-se de modelos sociais e estéticos impostos pelo Ocidente. $\mathrm{O}$ propósito é construir a nação moçambicana. (AFONSO, 2004, p.345)

A narrativa final "costura" as dores e tragédias com a esperança e o renascimento, onde simbolicamente da morte surge a vida, numa complementaridade que reflete a idéia de passagem para margens diferentes de um mesmo caminho; premissa que fundamenta a religiosidade predominante na maioria das comunidades moçambicanas e /ou africanas. "Rosita" pode, assim, ser lida como uma metáfora da nação.

Rosita, primeiramente, é uma imagem. Imagem fotográfica, televisiva, moçambicana. Foi notícia que percorreu o mundo e, hoje, ultrapassou a História e tornou-se ficção. A imagem data de 2000, ano de uma das mais catastróficas enchentes ocorridas em Moçambique; que, ainda hoje, é facilmente lembrada pela geração que teve acesso às notícias da época e que pode ser acessada por todos na internet. Muitos, ao redor do mundo, só souberam da existência de Moçambique porque as imagens da catástrofe tornaram real um universo africano, até então, pouco conhecido.

A imagem de Rosita imprime Moçambique numa memória coletiva. A primeira “impressão", interna, acontece com as reportagens jornalísticas sobre as enchentes; e, a ele, segue-se o noticiário internacional. A transposição para o registro literário ocorre com uma crônica de Mia Couto: "Rosita”, publicada em 05 de março de 2000, no jornal O Público de Lisboa $^{2}$. A publicação da estória como um conto se dá em 2001, em Na berma de nenhuma estrada. Assim, Rosita torna-se definitivamente uma personagem da literatura. Em nota de rodapé do conto, o próprio autor esclarece:

Escrevi esta estória com base em depoimentos que recolhi durante as cheias do rio Limpopo, em Março de 2000. Rosita é uma menina que, realmente, nasceu numa árvore. A sua mãe havia-se refugiado nesse que era o único ponto alto na paisagem inundada. (COUTO, 2003a, p.179)

\footnotetext{
${ }^{2}$ A informação consta no texto "Mia Couto: 'E a incurável doença de sonhar”" (SECCO, 2006 p.289) que reproduz um trecho da crônica citada.
} 
Os depoimentos citados por Mia Couto são as vozes dos seres comuns que povoam o universo do escritor, aqueles a quem ouve e/ou de quem ouve falar, os que são apenas citados nas vozes alheias e, muitas vezes, silenciados e/ou silenciosos. Dessas vozes anônimas o autor alimenta suas estórias, como ele próprio tem reiterado, em inúmeras ocasiões, ao falar da sua escrita. Uma delas é o nosso narrador-protagonista, que conta, em primeira pessoa, a história de sobrevivência de um homem rural, moçambicano, num mundo de enchentes e de guerras.

Essa narrativa é uma constituição de imagem através da palavra. O protagonista relata o que lhe ocorreu na enchente, quando o rio se fez mar e submergiu a sua terra (COUTO, 2003a, p.180), roubando-lhe o pouco que tinha, material e afetivamente, tendo ele sobrevivido sobre um telhado. À semelhança de um filme fotográfico, são impressas no papel as cenas de um relato ficcional. A proximidade temporal do conto com fatos ocorridos num espaço reconhecível, a inserção de um fato verdadeiro na ficção e a semelhança dos acontecimentos contados pelo narrador com os vividos por um imenso número de pessoas - na enchente moçambicana de 2000 -, leva-nos a ponderar sobre a existência de duas escritas paralelas. Uma seria visível na forma de conto e a outra, subjacente, poderia ser uma crônica, ou, em outras palavras, o registro no negativo do referido filme.

Nessa perspectiva, Mia Couto, enquanto escritor, assina a criação literária, mas é o cidadão que capta a imagem a ser retratada, com a sensibilidade do homem que acompanha o desenrolar das histórias verdadeiras do cotidiano. Retomando colocações anteriores, diríamos que "Rosita" é um momento de interação entre Antonio Emílio Leite Couto e Mia Couto; este último, o que constrói o texto com os sons, cheiros, cores, sabores e saberes africanos, imprime, agora, na sua escrita, as lágrimas do primeiro. A conexão entre ambos parece-nos estabelecida no texto intitulado "Colheita perdida", publicado na coluna "a opinião de: Mia Couto" no jornal Metical ${ }^{3}$ de Maputo, em primeiro de março de 2000, do qual transcrevemos um trecho:

Olhando os lugares onde estive há menos de um mês, agora completamente submersos, me vem um sentimento que já não é só tristeza. Um enorme cansaço. Uma desistência da alma,

\footnotetext{
${ }^{3}$ Jornal fundado e dirigido pelo jornalista Carlos Cardoso, autor de investigações e denúncias públicas sobre corrupção, crime organizado (drogas e lavagem de dinheiro), especulação imobiliária e enriquecimento repentino de dirigentes políticos em Moçambique, e que foi assassinado em 22 de novembro de 2001, ao sair da sede do jornal, em Maputo. Mia Couto é autor da mensagem lida nos funerais do jornalista de quem era amigo. Em 2001, dedica-lhe o livro Na berma de nenhuma estrada ("Ao Carlos Cardoso que me enviou o poder da verdade contra a mentira dos poderosos") e, em novembro de 2002, faz a apresentação da versão online do Metical. Já, em julho de 2002, no seu discurso na cerimônia de premiação dos "12 melhores romances de África”, em Cape Town, referira-se a ele como um herói moçambicano (ao lado de Eduardo Mondlane e Samora Machel), que é publicado, em 2005, no livro Pensatempos: textos de opinião, sob o título "Que África escreve o autor africano?" (COUTO, 2005, p.63); da mesma obra consta o texto "Não bastam palavras" (COUTO, 2005, p.97-100) correspondente à mensagem dos funerais do jornalista.
} 
dentro de mim. A mágoa profunda de ver perdida a colheita de esperança que os moçambicanos semearam depois da guerra.

Esta gente - aos milhares - que espera em cima do último telhado está desenhando outros deuses: Os helicópteros que descem dos céus para os salvar. Vejo as imagens na televisão e não tenho outra defesa contra a lágrima. Como uma erva já sem raíz (sic), a mãe com seu filho nas costas vai subindo nos céus. Aos poucos é engolida pela barriga da máquina voadora. Lá em baixo, tudo é rio, torrente e lama. A morte servindo-se dos mesmos materiais da vida. (COUTO, 2000, p.3)

Ao início, referimos à imagem de Rosita na sua configuração simbólica, mas, por outro lado, temos a imagem fotográfica real, de Sofia Pedro segurando no colo sua recémnascida embrulhada numa capulana ${ }^{4}$. Essa foto, ampla e reiteradamente divulgada mundo afora, tornou-se uma referência visual de uma catástrofe, uma tradução concreta, dos problemas de uma nação africana, e do continente por extensão. A materialidade desse registro possibilitou, não só a articulação simbólica, mas fomentou (re)ações materiais, instigando a solidariedade em diversos países. A esse respeito encontramos, exemplarmente, duas intervenções de Mia Couto:

Conto-vos agora um pequeno episódio, real [...]. Estávamos em plenas cheias, as grandes inundações de 2000, quando fomos descobertos pelas cadeias internacionais de televisão (é incrível como apenas a desgraça converte os pobres num assunto). Nessa altura, o Hotel Polana converteu-se subitamente num centro mundial de telecomunicações, uma base de operações da BBC, CNN e outras estações em disputa pela tragédia. [...]

Nesses dias fomos o centro do universo. Para muitos neste mundo que se quer aldeia global, o nome e o rosto de Moçambique faziam estréia. Não era apenas a Rosita que nascia em inéditas condições (em cima de uma árvore). Para uma larga faixa de telespectadores por esse imenso mundo, acontecia o nascimento da nossa própria imagem enquanto país. ${ }^{5}$ (COUTO, 2005, p.68)

Há cinco anos atrás, os rios de Moçambique incharam e, num impulso de fúria, levaram vidas, lavaram terras, semeando morte e destruição. Há mais de um século que os nossos rios não transbordavam assim. Fonte inesgotável de vida, a água mostrou que pode semear o luto. $\mathrm{O}$ mundo inteiro se chocou, atónito, perante as imagens da teimosa força dos vivos, da mão do Homem estendendo-se solidária, perfazendo a maior das pontes, essa que une o desespero à esperança. Chegou, sobretudo, a imagem da menina nascendo em cima da árvore, testemunha da vontade indomável de, mesmo no meio da vertigem apocalíptica, nascermos todos numa outra vida.

Os moçambicanos conhecem a dor de tudo perder. Porém, mais do que a dor, nós conhecemos o doce conforto da solidariedade dos outros. De todos os continentes nos chegou o pão, a água, o medicamento, os materiais para tudo recomeçarmos. Com esses sinais de afecto fizemos sempre do sofrimento uma força para refazermos a esperança. ${ }^{6}$ (COUTO, 2005, p.101)

O escritor fala do nome e do rosto de Moçambique nascendo com Rosita, e temos a percepção da dor presente naquelas águas, apocalípticas, que devastaram parte de um

\footnotetext{
${ }^{4}$ A referida fotografia encontra-se disponível em: http://w3.ualg.pt/ jdias/GEOLAMB/GAn_Casos/Mocambique/Mozambique.html

5 Trecho da palestra na Conferência das Telecomunicações de Moçambique (TDM) sobre "Globalização da Tecnologia num Mundo Informatizado”, ocorrida em abril de 2001, em Maputo, Moçambique. Publicado em COUTO, 2005, p.65-73, sob o título "A mosca ou a aranha?".

${ }^{6}$ Parte do "Texto do abaixo-assinado da sociedade civil para o secretário-geral das Nações Unidas, Janeiro de 2005", publicado em COUTO, 2005, p.101-102, sob o título "Um abraço solidário de Moçambique”. À época ocupava o cargo Kofi Annan, representante de Gana. O texto reporta ao tsunami de 26 de dezembro de 2004.
} 
continente, pois outros países também foram afetados na ocasião. As enchentes são cíclicas naquela área, assim como tufões que atingem a costa do Oceano Índico potencializando os efeitos das inundações; mas, sempre que a natureza destrói, ela própria convida a recomeçar, revitalizando a terra ressequida. O homem local, submetido às intempéries e catástrofes, supera os desígnios divinos e desmandos humanos e é dele, em essência, a fotografia com a imagem de Rosita.

A leitura de imagem é uma possibilidade aventada por Mia Couto, num texto ${ }^{7}$ em que comenta o trabalho, e discorre sobre o papel dos fotógrafos na África - os "imaginógrafos" -, na sua denominação. Destacamos dois recortes, que sincronizam com o que entendemos seja um significado do registro fotográfico de Rosita:

Eu não apenas vejo. Eu ouço a fotografia. O contacto visual acorda em mim sons que deveriam ter rodeado o momento fixado em imagem. Apto apenas para inscrever a imagem, o papel não foi capaz de expulsar as vozes. Vitória do mundo da oralidade ainda dominante em África: a mancha gráfica sujeita-se ao poder do verbo. A imagem é tanto mais bela quanto ela for auditiva, evocando sonoridades do momento. A escrita (e a foto enquanto um modo de escrita) é vencida por outra lógica. Neste jogo de miragens e ilusões, África desnuda-se para melhor se ocultar. Aqueles que acreditam ter focado essências apenas tocaram aparências em movimento. (COUTO, 2005, p.75, grifos do autor) ${ }^{8}$

O nomes que assinam estas fotos revelam uma África que os africanos, a um tempo, reconhecem e desconhecem. Estão aqui retratos do Homem experimentando os limites da sua condição humana, estão aqui as fundas mutilações causadas pela guerra, pela fome, pela doença. Mas esses flagrantes de miséria não apelam para a comiseração. Paira em todas estas imagens uma outra dimensão, a epopeia de povos que se descobrem em estado de adolescência. Como designar, então, a profissão destes caçadores de fascínio? Fotógrafo é um termo que não basta. Melhor seria chamá-los de imaginógrafos. Com eles todos sangramos da mesma ferida, todos reacendemos igual esperança, todos ousamos de novo assaltar o futuro. Eles manejaram o poder mágico da imagem: desocultar os múltiplos sentidos do acontecido, libertar o tudo que poderia ter sido naquilo que simplesmente foi. (COUTO, 2005, p.83, grifos nossos)

A história do nascimento de Rosita, por sua vez, pode ser lida como uma metáfora da força, da resistência e da capacidade de (re)nascer do homem moçambicano. Realidade e ficção dialogam por todo o texto no dito e no não-dito, no escrito e nas entrelinhas, naquilo a que Maria Fernanda Afonso (2004, p.366) chamou de "uma maneira fora do comum de olhar o mundo, de sonhar a realidade, de lhe proporcionar um tratamento que a transfigura". É o que encontramos em Gaston Bachelard (2001, p.6), na assertiva: "No reino da imaginação, a toda imanência se junta uma transcendência".

O narrador-protagonista e o seu "velho companheiro" (COUTO, 2003a, p.179) - o boi Makalatani -, as vozes sem nome dos que avisam sobre a enchente e dos seus "colegas de

\footnotetext{
7 “Publicado em 'Semanal, Única - Reportaje', El País, Janeiro de 2003”, conforme indicação na obra Pensatempos: textos de opinião, sob o título "As vozes da foto", p. 75-83, constante em nossas referências.

${ }^{8} \mathrm{O}$ destaque em negrito corresponde a grifos nossos.
} 
viagem" (COUTO, 2003a, p.183) - resgatados como ele -, o soldado sul-africano "que não falava português" (COUTO, 2003a, p.182) e Sofia Pedro que lhe apresenta Rosita - a "menina mais recente que um orvalho" (COUTO, 2003a, p.183) - são personagens do tempo real "transfiguradas" para o tempo da memória. Nesse sentido, acompanhamos a proposição de Fernanda Cavacas (2006, p.69-70) de que Mia Couto, ao recorrer aos elementos presentes na cultura moçambicana, procura "transmitir a constância, a unidade e o reconhecimento característico da identidade numa intenção didáctica, iniciática e simbólica evidente" e, desse modo, contribui "para a memória em construção, memória comum que respeite o chão dos antepassados, o solo sagrado da pátria moçambicana" (grifos do autor).

A estória inicia com um narrador-protagonista, sem nome, contando o que se passou com ele há cinco dias, quando foi visitado por pessoas que alertavam sobre a grande enchente que chegaria brevemente. Esse homem, cujo patrimônio é a casa e algumas cabras e a riqueza maior é um boi, companheiro suave e fiel, recusa-se a acreditar que a natureza destruirá o pouco que lhe sobrou dos anos de guerra e de seca. Conhece o rio e a chuva, mas desconhece as ciências da hidrologia e da hidrometria, da climatologia e meteorologia.

Esse narrador sabe dos horrores cometidos pelos homens com suas lutas sangrentas, que destruíram famílias, aldeias, animais e plantações. Conhece as medidas do céu com suas águas abençoadas fertilizando a terra moribunda e ressequida, nos desígnios divinos. Entende as rezas e cerimônias que pedem e agradecem a cada recomeço, mas não entende as previsões que falam numa linguagem distanciada da sua compreensão. Diz ele: "Disseram que o rio ia enlouquecer. Que eu não sabia mas este rio ${ }^{9}$ ligava com outro e esse outro ${ }^{10}$, por sua vez, se ligara à parte do céu onde os deuses guardam toda a chuva" (COUTO, 2003a, p.179). Mais adiante continua: "Mais uma vez, os avisos para sairmos. Outra vez deslocados? Esses que agora nos alarmavam sabiam, com tamanha certeza, dos futuros? Um pobre abandona, ligeiro, a sua pobreza? (COUTO, 2003a, p.180).

O rio do narrador e o rio dos que "alarmavam" não dialogavam, não eram compatíveis, não podiam falar a mesma língua; os sinais que eles emitiam não tinham a mesma

\footnotetext{
${ }^{9} \mathrm{O}$ rio referido pela personagem é o rio Limpopo, que atinge o seu pico de cheia em 26 de fevereiro; os alertas de evacuação são renovados. Dados mais precisos sobre as ocorrências à época estão disponíveis em: http://w3.ualg.pt/ jdias/GEOLAMB/GAn_Casos/Mocambique/Mozambique.html; http://www.diariodaafrica.com/2008/10/secas-e-cheias-em-moambique.html e http://w3.ualg.pt/ jdias/GEOLAMB/GAn_Casos/Mocambique/Mozambique.html

${ }^{10} \mathrm{~A}$ fala do narrador refere-se à rede de comunicação entre vários rios e afluentes, no caso a bacia hidrográfica do rio Limpopo que abrange cerca de $415.000 \mathrm{~km}^{2}$. Dados específicos estão disponíveis em:

http://pt.wikipedia.org/wiki/Rio_Limpopo
} 
codificação. Mia Couto, em uma conferência ${ }^{11}$ no Ciclo Biologia na noite, na Universidade de Aveiro, Portugal, em 2006, ao falar sobre o rio, estabelece um enfoque que pode conter códigos comuns a ambas as falas:

Acreditamos que todos sabemos o que é um rio. No entanto, essa definição é quase sempre redutora e falsa. Nenhum rio é apenas um curso de água, esgotável sob o prisma da hidrologia. Um rio é uma entidade vasta e múltipla. Compreende as margens, as áreas de inundação, as zonas de captação, a flora, a fauna, as relações ecológicas, os espíritos, as lendas, as histórias. É uma rede de entidades vivas, um assunto mais de Biologia que de Engenharia. Habituados a olhar as coisas como engenhos, esquecemos que estamos perante um organismo que nasce, respira e vive de trocas com a vizinhança. (COUTO, 2009a, p.55)

Esse homem marcado pelos anos de perdas e fugas, de regressos e recomeços, só encontra no velho e bondoso Makalatani uma criatura com quem dialogar. Em culturas rurais moçambicanas, como em outras regiões da África, os animais ultrapassam o sentido ocidental de utilidade e fazem parte de um todo chamado simplesmente de natureza, onde o homem também se inclui. Não há diferença entre natureza e cultura, nem mesmo uma palavra específica para designar esta última, tudo o que existe, na terra, na água e no céu, está contido na primeira. À semelhança do que expõem Chevalier e Gheerbrant (1996, p.137) sobre a simbologia do boi, Makalatani assume o significado de "bondade", "calma" e "força pacífica":

Falei com Makalatani enquanto ele comia, tranquilo. Decidimos os dois esperar. Não podia ser: já na guerra nos havíamos separado. Ambos perdêramos tudo, há tão pouco tempo. Quantas vezes podemos perder tudo na vida? Fazia nem dez anos que fugíramos dos tiros, cada qual para sua sobrevivência. O meu companheiro, o velho Makalatani, onde ele se metera nesses anos de guerra? Acreditei que não tivesse sobrevivido. Mas quando regressei a Chokwé ${ }^{12}$, lá estava ele me esperando. Fiel, no lugar onde nos separáramos. A violência não o tinha azedado. Todo ele se mantinha na mesma doçura, disposto a recomeçar, sendo sempre o pouco contra o nada. (COUTO, 2003a, p.179-180)

O protagonista e o boi permanecem em sua casa, assim como muitos vizinhos, e a previsão se concretiza quando percebem amedrontados que "o céu ganhou cor de terra, lembrando cuspes do diabo. As nuvens pesavam como se feitas de lama. Em tais densidades, o céu deixava de ser morado por aves" (COUTO, 2003a, p.180). Já não há mais tempo de fuga, e a chuva, fonte de bênçãos divinas, se torna destruidora, apocalíptica; o rio "caligrafia da água", "liquefaz a carne térrea da África" e o "continente se oceanifica" (COUTO, 2003b, p.77-78). Prossegue o narrador:

\footnotetext{
${ }^{11}$ O texto, na íntegra, está publicado sob o título "Rios, cobras e camisas de dormir" em E se Obama fosse africano? e outras interinvenções, p. 61-63, constante em nossa referências.

${ }^{12}$ Distrito da província de Gaza. Dados complementares se encontram disponíveis em: http://pt.wikipedia.org/wiki/Ch\%C3\%B3kw\%C3\%A8.
} 
E, logo, vieram as chuvas, cascateando ${ }^{13}$ a terra. Águas imensas, demoradas, cada gota grávida e ávida. Em todo o lado nasciam veias, todo o recanto se convertia em afluente. E o rio inchou, transbordou até cobrir a imensidão.

Na primeira madrugada, a chuva já tinha desossado a estrada, engolido a ponte, mastigado os campos. Deus perdera mão nas águas. A tristeza sorriu, dentro: sempre eu quis ver o mar. Agora, o mar me veio ver a mim. (COUTO, 2003a, p.180)

Nesse ínterim, o único ser tranquilo era Makalatani, que pastava "alheio à chuva e aos presságios" (COUTO, 2003a, p.180), enquanto seu dono "olhava o tempo, farejava o rio" (COUTO, 2003a, p.180). A chuva e o rio continuam seu percurso teofânico e o homem amedrontado, sabedor da natureza dos rios e decifrador do recado das nuvens, traz da memória recente as imagens que espelham o devir:

Olhava o tempo, farejava o rio. Conhecia suas parecenças - tempo e água. Ambos me levaram filhos, sonhos, riquezas. Já sentei na margem do tempo. Parei minha vida ali, deitado na berma. Descobri depois que não há margem. Tudo é correnteza, a margem só na aparência está parada. Essa corrente do tempo foi quem levou minha mulher, meus filhos, tudo. (COUTO, 2003a, p.180-181)

Na noite seguinte a inexorável subida das águas obriga todos a buscarem refúgio em qualquer local elevado. Tudo em volta desaparece carregado pela correnteza. Conta-nos o narrador-personagem:

Escalei a árvore, subi o telhado no armazém. Makalatani subiu comigo. Ele parecia tonto, desequilibrista ${ }^{14}$. Depois, se deitou, como se nada mais houvesse.

Olhei mais longe, para as vizinhanças, não vi senão água. E pensei na vizinha Sofia Pedro. Ela estava grávida, bem no final do prazo. Teria conseguido escapar? Gritei por seu nome. O barulho das águas me apagou. Só Makalatani me olhava, com aqueles olhos de mulher desnudada. Eu ia perdendo natureza para pessoa. Minha pele já estava cozida, engrutadinha ${ }^{15}$. Não tardaria que eu vertesse em peixe, todo coberto de escamas. (COUTO, 2003a, p.181)

Ilhados, na sua solitária resistência, o narrador e o seu boi, (re)significado, bebem "água doente" para sobreviver, até que o imenso rio mostra "bois e homens flutuando, inchados, na corrente" (COUTO, 2003a, p.181). O protagonista, dividido entre resistir ou se abandonar na correnteza, conversa com o companheiro que vê ao seu lado, "tão suave, sabedor da espera" (COUTO, 2003a, p.182). Amparado pela tranquilidade do velho Makalatani rejeita o líquido que "contamina as entranhas" e transporta a morte que, nas suas palavras "é um outro rio: de uma vez em quando, ela salta a margem e nos inunda com tamanho de um oceano" (COUTO, 2003a, p.181). Seus dedos sangram no esforço de se agarram às tábuas, delira "devido das fomes" e "assiste o seu próprio falecimento" (COUTO, 2003a, p.182).

\footnotetext{
${ }^{13}$ Cascateando: em forma de cascatas.

${ }^{14}$ Desequilibrista: equilibrista que perdeu o equilíbrio (de equilibrismo).

${ }^{15}$ Engrutadinha: enrugada, com depressões e cavidades em forma de grutas.
} 
As palavras do narrador vão compondo dois quadros, o que ele, no seu delírio, vê; e o outro, que a razão nos leva a visualizar. O boi não poderia estar ali, não subiria na árvore ou no telhado, mas sabemos que há uma presença de Makalatani, já que ele é o fundamento da resistência do seu dono, como o próprio reconhece ao dizer que o animal lhe "emprestava sobrevivências" (COUTO, 2003a, p.182). Subjacente à narrativa, imagens de outras catástrofes presentes em nossa memória vão se agregando àquelas constituídas pelo texto ficcional. Na continuidade da narrativa, o protagonista relata o seu resgate:

\begin{abstract}
No quarto dia, eu já nem acertava em nenhuma visão. Tudo se desfocava. Foi então que escutei uma nuvem que baixava, ruidosa. Era uma nuvem a motor. Ficou em cima, rodopiando como uma águia. Desceu um anjo branco dessa nuvem, me segurou. Eu já me aceitava a tudo. Menos deixar o meu companheiro para trás.

[...]

O homem me gritou. O barulho, o salpicar da água, tudo aquilo, de repente, me acordou. $\mathrm{O}$ anjo era, afinal, um soldado sul-africano que me abria os braços, suspenso numa corda. A nuvem era um helicóptero que ventoinhava ${ }^{16} \mathrm{em}$ cima do armazém onde nos abrigávamos. (COUTO, 2003a, p.182)
\end{abstract}

A partir daí se estabelece, na ficção, um diálogo entre o real e o onírico, e o "anjo branco" se transforma num soldado sul-africano que só fala uma língua de “ordens, obediências despachadas" (COUTO, 2003a, p.182) e não entende as falas do protagonista. Para desespero do seu dono, que se recusa a ser salvo sem a sua única riqueza, o boi que "desviou a cabeça, medroso das alturas" e "teimoso, quadrupetou-se" (COUTO, 2003a, p.182-183) não é levado para o helicóptero. Ao encontrar seus vizinhos já resgatados, ele dá vazão a sua revolta por ter sido salvo "contra sua vontade":

\title{
- Viram, compadres? Fui obrigado a deixar meu boi em cima do telhado. \\ - Que boi? - perguntaram. \\ - Meu boizão, chamado Makalatani, por baptismo que lhe dei.
}

Mas os outros, salvados como eu, se espantaram. Não havia nenhum boi junto de mim. E um outro até se adiantou: ele vira, arrastada pela torrente, a minha chifraria. Assistira àquilo há mais de dois dias. O animal já devia estar padecendo de pouca vida, se via um só chifre apontando os céus. Afinal nunca houvera um boi no meu telhado, eu devia estar delirado, motivo das águas sujas que bebera. (COUTO, 2003a, p.183)

As informações dos seus pares trazem o narrador de volta à realidade, sozinho "sem companhia para recomeçar a vida" (COUTO, 2003a, p.182) fica "calado como um órfão" olhando os "colegas de viagem" que, como ele, "pingavam: água, medo e espanto" (COUTO, 2003a, p.183). Esse homem sobreviveu à guerra e a seca prolongadas, recomeçou com a "chuva abensonhada”, como relembra Carmem Lucia Secco (2006, p.289), e agora está novamente "na berma de nenhuma estrada". Mas, é exatamente na "maldição das águas"

\footnotetext{
${ }^{16}$ Ventoinhava: produzia vento, as hélices giravam feito ventoinha.

${ }^{17}$ Quadrupetou-se: empacou, estacou, fincou as quatro patas, espetou-as, (quadrúpede + espetar).
} 
como refere a autora que o protagonista vai encontrar o sinal da vida que supera a morte. Ali, resgatada como ele, reconhece Sofia Pedro, a vizinha que perdera em meio ao "barulho das águas" e é sob o ruído dos motores do helicóptero que a ouve dizer: “- É Rosita, essa é minha Rosita." (COUTO, 2003a, p.184).

Entre o medo, a solidão, a fome, a sede, o cansaço e a dor, há uma menina, embrulhada numa capulana, "ninhada em cima da árvore” (COUTO, 2003a, p.183), cuja visão traz a vida de volta aos olhos "desfocados" do narrador-protagonista, como ele nos conta, ao final da estória:

Calei-me com meus botões. Olhei a criança, meus olhos se acertaram. A menina parecia chorar. Mas não se escutava, tudo era abafado pelos motores. Sofia Pedro pegou na menina e a colocou junto ao peito. A voz estreitinha de Rosita foi crescendo, sobrepondo-se aos motores do helicóptero. Tudo se amaciou dentro de mim, uma inundação me afogando o coração. E, de novo, me vi em nuvem, flutuando como um navio. Eu viajava, junto com os meus, para esses nunca vistos campos onde meu boi pastava o matinal cacimbo.

Sim, nesse destino haveria terra. De novo, o infinito território da vida. E Rosita já nascia em mim. (COUTO, 2003a, p.184)

O final da narração é um início, um recomeço. O protagonista encontra na imagem daquela menina a vida que surge da morte. Sofia Pedro venceu a fome, a sede, a correnteza destruidora das águas lamacentas e trouxe ao mundo uma nova vida: Rosita, o início de um ser. Mas Sofia Pedro é também um recomeço, é mulher sem posses materiais que vai voltar para a sua terra quando as águas se forem, e vai criar seus filhos: ela é, pois, o símbolo do eterno recomeço.

Pensamos, desse modo, em futuro como o Ocidente conceitua, mas devemos considerar que ele inexiste para muitas culturas africanas, onde não há fronteiras entre os tempos, porém, um contínuo movimento da vida, um só percurso que obedece às leis celestes, onde deuses e antepassados comungam com os homens uma mesma dimensão. Assim, se os mortos se comunicam é natural e, portanto, é parte do agora; eles não estão num passado porque já viveram, estão no presente porque fazem parte do todo ininterrupto. Na natureza isso também ocorre, os ciclos se alternam sem divisões, tudo se modifica constantemente, do mesmo modo que a água que ora é a fecundidade e ora é a destruição.

O conto situa um tempo marcado no passado imediato do narrador. Os dias e as noites, comuns a todas as culturas, aqui não estão ligados a idéia de datação, mas às ocorrências da natureza. Para as personagens, a alternância de dia e noite não é parâmetro de passado ou futuro, é um decorrer de ciclos; o fato é concreto, e a origem pertence ao domínio mítico, como circunstâncias da Criação. Se à escuridão sucede a luz, à tormenta segue a estiagem, 
nenhuma existe sem a outra, são complementares. A água inscreve-se como fundamento indiscutível da mesma Criação, não se sujeita a classificações humanas, é desígnio divino.

A imagem de Rosita estabelece um registro na memória do protagonista quando ele, no seu de nascimento da menina, a morte - com quem ele estivera todos aqueles dias - como sequência. Na simbologia, conforme Chevalier e Gheerbrant (1996, p.640), uma das possibilidades da noite é ser o "tempo das gestações e das germinações", onde se "fermenta o vir a ser" e ocorre a "preparação do dia, de onde brotará a luz". Nesse sentido, água e terra também perpetuam a complementaridade, e o narrador renasce quando da água mortal surge a menina, que lhe devolve o sonho: o "destino onde haveria terra". A menina é assim imagem da vida constituída pelas palavras da personagem da ficção e, paralelamente, quando é transposta para a realidade pela imagem fotográfica.

"Rosita", na perspectiva de nossa análise, traz a constituição da memória num tempo presencial, através da passagem da água pelo discurso narrativo, que, por sua vez, é constituído a partir de uma memória real de um tempo destacável - o da grande enchente; a época será resgatada pelos acontecimentos e não pelo dia/mês/ano em que ocorreu. $\mathrm{O}$ ano de 2000 é o marco da enchente e da menina da foto, é também o tempo das palavras do contador da estória; ficção e realidade partilham dos mesmos eventos e de imagens semelhantes, mas as registram de modos diferentes.

Mia Couto, em entrevista, perguntado sobre qual a importância de elaborar uma ficção associada aos problemas sociais, responde: “Acho que não existe simplesmente ficção. Todo texto sempre tem essa relação de fronteira mal desenhada entre o que é real e o que é ficcional. O escritor brinca com isso, e ele próprio não sabe o que é" (COUTO, 2009b). Consideramos que este conto é um exemplo dessa "fronteira mal desenhada" que, nessa perspectiva, permite a imbricação de ambas através da constituição de imagens de uma memória posterior.

\section{Referências}

AFONSO, Maria Fernanda. O conto moçambicano: escritas pós-coloniais. Lisboa: Caminho, 2004.

BACHELARD, Gaston. $O$ ar e os sonhos: ensaio sobre a imaginação do movimento. Tradução de Antonio de Pádua Danesi. São Paulo: Martins Fontes, 2001.

CAVACAS, Fernanda. Mia Couto: palavra oral de sabor cotidiano/palavra escrita de saber literário. In: CHAVES, Rita; MACÊDO, Tania (Orgs.). Marcas da diferença: as literaturas africanas de língua portuguesa. São Paulo: Alameda, 2006, p. 57-73. 
CHEVALIER, Jean; GEERBRANT, Alan. Dicionário de símbolos. 10. ed. Coordenação de Carlos Sussekind. Tradução de Vera da Costa e Silva et al. Rio de Janeiro: José Olympio, 1996.

COUTO, Mia. Cronicando. 7. ed. Lisboa: Caminho, 2003b.

. Colheita perdida. O Metical, Maputo, n. 679, 01mar. 2000. disponível em: http://www.cip.org.mz/metical/

Entrevista. Globo.com - G1 > Pop \& Arte. 26/06/09b - 16h16 - Atualizado em 26/06/09 16h52. Disponível em: http://g1.globo.com/Noticias/PopArte/0,MUL1207946-7084,00.html E se Obama fosse africano? e outras interinvenções. 2. ed. Lisboa: Caminho, 2009a.

. Na berma de nenhuma estrada e outros ensaios. 3. ed. Lisboa: Caminho, 2003a.

Pensatempos: textos de opinião. 2. ed. Lisboa: Caminho, 2005.

SECCO, Carmen Lucia Tindó. Mia Couto: e a "incurável doença de sonhar". In: SEPÚLVEDA, Maria do Carmo; SALGADO, Maria Tereza. África \& Brasil: letras e laços. São Caetano do Sul: Yendis, 2006, p. 267-298. 